\title{
How the people acquire language?: A case study on Virendra Language acquisition
}

\author{
Tatu Zakiyatun Nufus' ${ }^{1)}$, Atik Yuliani') \\ 1)2)UIN Syarif Hidayatullah Jakarta, South Tangerang, Banten, Indonesia \\ Zakiyah83@yahoo.co.id
}

\begin{abstract}
The language acquisition process can be seen as a running parallel throughout a child's life every day, it happened for every human who interacts with other people to share information since they were a child. It looks closely at the acquisition of the early age of Virendra, he was a child under 5 age who lives in the Sundanese environment and he is not familiar with English as a foreign language. Virendra was familiar with Arabic literature previously in his house, and he knows English in the formal school of his Playgroup up to now in kindergarten, the writer tried to report this case using a descriptive method. The data is collected while he was used the language in the school and how his parents influence his language acquisition in the house. And it is conducted to know how well Virendra's comprehension in producing language. Beside it, this study is expected to the parents to lead the child in using language.
\end{abstract}

Keywords: language acquisition, theories of language acquisition

Citation APA Style: Nufus, T. Z., \& Yuliani, A. (2020). How the people acquire language?: A case study on Virendra Language acquisition. English Language in Focus (ELIF), 2(2), 123-130.

\section{INTRODUCTION}

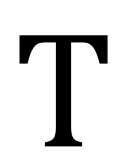

he appropriate age for introducing English as a second language to young learners remains as one of the unresolved issues in the field of second language acquisition. Are younger learners better than older learners in acquiring a second language? Does early exposure to the Target Language (TL) yield better results? Do younger learners acquire a second language better and faster in 'formal' learning situations? These questions raise when the learners are taught to learn the language, it has not only needed a short answer with yes/ no answer, but it needs a process and solution to face this unresolved issue.

Naturally when children born, they can use many languages in their interaction, because children are born ready to become bilinguals and multilingual (Baker, 2011). To enhance children's language, a lot of stimulations to language are essential. In some situations, producing bilingual children is easy and natural; in others it can be a struggle. A lot of factors affect the process, such as encouragement from both of the parents at home and the community. The way how parents treat 
the children enables them to imitate the language that the parents use, and they will practice it in the interaction process in the large community among them (Goodz, 1989).

In the bilingual and multilingual community, there is a great need to master two or more languages for operating daily activities successfully. Because mastering many languages will make the children easier to express their feelings and to communicate with others in real life and this situation strongly supports the children's bilingualism. Language shaping is important in families that judge and create bilingualism in the community. This means that it is important for the parents to motivate children's attitudes towards their languages and a variety of pleasurable environment for language growth is also very important to encourage learners' motivation in learning.

The situation that appears in Virendra language acquisition is to be similar in the research that happened in Aceh. Studies which is conducted with Yusuf (2009) on how Keisha can acquire the language and the studies have demonstrated that infants can acquire the language easily through many factors including the environment, parents and also motivation. In conducting this research, the writer has chosen Virendra as the subject of research, Virendra is a small boy with three years old, he was living in Sundanese area were around him also use mostly Sundanese as the means in the interaction process, Virendra lives with his parents who know Arabic as his first foreign language because his parents were teachers in one school. And Virendra was introduced Arabic and English as the foreign language of his after Virendra has mastered the first language, in his room the parents hang the pictures out with both Arabic and English literature to enable him in knowing how to indicate the language.

Due to the limited time, this report is conducted in a very short one. The research is done in three weeks to see Virendra's language development, from age $3: 1$ to $3: 2$. And the data collection started in 2019 from January $10^{\text {th }}$ to February $3^{\text {th. }}$ And this report has a question to use as a guide in conducting the report as follows: 1) Words in what language does he knows and speaks most? 2) What factors enable him in using language? This report is conducted to see the language development of Virendra during his age of $3: 1$ to $3: 2$ years old. And this report is expected to answer the above questions and also to give the information for his parents to see and give full attention to language development.

Language is an important means to convey messages and information to other people, we need language to share information and to build relationships with others. Since the people were born they have to communicate with their environment directly by their language, and the process of receiving language has many ways, it depends on the individual, and situation of learning and acquisition, learning is considered as a conscious process, knowing the rules, being aware of them, and being able to talk with them, while acquisition is a process by which children unconsciously acquire their native/first language. In language 
acquisition, the focus is on communication or reception of a message to give a meaningful message to the others.

The language acquisition process can be seen as a running parallel throughout a child's life every day. The process begins in the early life of humans and requires a healthy start, sufficient opportunities, and exposure to a caregiving environment that allows the child's innate predisposition to learn to communicate to function (Rossetti, 2000). Children learn at a different rate, the speed of learning is influenced both by innate abilities and environment, and the development of language acquisition of all children occurs gradually through interaction with people and environment, and language acquisition is going rapidly, it happens to children in their interaction with the environment, when they were only in two years they produced already the first word at around the age one until the major part of the grammar is acquired at around three, and exposure of the children is necessary to learn the language. It caused off the innate ability to acquire language that must be triggered by language exposure and feedback from the environment. That is so long as a child hears any language, when they reach the adult age (critical period) they will learn it perfectly (Freeman \& Long, 1991).

In acquiring the language, the learners have some factors, which can give influences in creating learners' language. as stated in the research of Yusuf that to enhance children's infant bilingualism, parents should continuously provide them with lots of exposures towards their targeted languages, create a pleasurable language learning environment and most of all, must be very patience in encouraging bilingualism toward them (Yusuf, 2009).

Naturally, the young learners acquire the language based on what they see, and hear, the learners use the language without thinking on its rule, and because they have the ability in imitating the teachers did in the classroom. These are similar to the theories of the language acquisition proposed by some researchers. 1) Imitation theory, where children produce what they hear and learn by positive reinforcement when right, and negative reinforcement when wrong. 2) Innate hypothesis, where humans are born 'ready' for languages with a Language Acquisition Device (LAD), an area that cannot be pinpointed in the brain, but it is generally presumed to exist through the neurological networks we have developed. 3) Critical age hypothesis, where the existence of a 'Critical Period' with language acquisition, as beginning at age two and ending around puberty within a fixed period, puberty or around 2 to 7 years old (Yuvaraj, 2009). 4) Innate ability to acquire language must be triggered by language exposure from the environment. That is, so long as a child hears any language when they reach this critical period, they will learn it perfectly (Lenneberg as cited in Yusuf, 2009).

Those theories implied that the young learners acquire language through imitation on what they hear and see, they can learn everything through their environment, and the learner has the age with categorized as critical period which enables them to learn anything better. 
The critical period is in the beginning at age two and ending around puberty. In this term the children have their interest in learning. And It can be described when the young learner sees and hear what the teacher says it enables them to imitate what the teachers did at that time, and for several factors the young learner has a good innate capacity in learning. And it simplifies them to receive the input in learning.

Fromkin, Rodman, \& Hyams (2003, p. 326) explained some generalization about children's language acquisition as follows. 1) Children do not learn a language by storing all the words and all sentences in some giant mental dictionary. The list of words is finite. 2) Children learn to construct sentences that most of which they have never produced before. 3) Children learn to understand sentences they have never heard before. 4) Children then must learn the 'rules' that permit them to use language creatively. To acquire language, need several factors, formal and informal situations, second language acquisition is necessary to acquire conscious and unconscious one, the language acquired unconsciously and language we can easily use in spontaneous because it can be produced when we need it. And to learn second language acquisition at least there are four major that should be concerned deeply.

Young learners learn and acquire something through the innate capacity of theirs and environment, children produce what they hear and see among the social interaction and they learn by positive reinforcement when right, and negative reinforcement when getting wrong and mistake. And the environment gives a great impact to create children's minds in using language or in their interaction process among the environment. The children might involve their language in a different process. They acquire language based on the capacity of their brain, and the children try to use the language based on their previous input through the environment, it is because of all the children are born with some kind of language processor, a black box or language acquisition device which allowed them to formulate rules of language based on the input they received. Therefore, the children are ready to accept materials that allowed them to use and process it in their mind.

The younger learner is said to receive better input than adults, input which provides the children with clearer samples from which to learn the rules of language, children also enjoy opportunities for language play with their native-speaking peers, through which they get phonological practice, and a younger learner receive a larger amount of input. The input that the children get enables them to make an interesting interaction with others.

Language has the relationship to the intelligence of the learners as a fundamental role in language acquisitions, in the performance intellectual tasks and evaluation of intellectual ability. Some of the theories show the inevitable link between the cognitive and language development in children. Piaget's theory reiterates that any kind of teaching can be effective only when the child can assimilate what is said and done, a concept he termed as 'learning readiness' (Sande, 1998). Penfield and Roberds (1959) and 
Lenneeberg (1967) shows that two halves of the brain (the left and right hemisphere) become specialized for different function around puberty that called lateralization before puberty, they argued a critical period exists during which the brain is more plastic and allows among others things, the transfer of function from one hemisphere to the others when the former has been injured and for new patterns of behavior to be efficiently processed (cited in Yuvaraj, 2009).

Those aspects above indicate that the learners can learn everything based on the environment, because the children are good imitator on what they like and they hear, the capacity of their brain and their cognitive style also affect the children development in language, and the previous input which gets from many aspects of the environment and the neurological aspect that enables them to reproduce the language. And those four factors have a great influence to create children mind in producing language.

\section{RESEARCH METHODOLOGY}

ح his research used descriptive method in finding data and information of how Virendra can acquire the English language, the researcher used observation as the instrument to gain the data on what Virendra activities in his environment, and to get this report the researcher takes the observation process for one month, it is not reported the activities in his school but mostly in his environment. Although it has only a short time but the writer expects to get reliable data based on the objective of this study, therefore it can motivate parents to lead the daughter in using appropriate language. Virendra is the writer's child, he was 3:1 years old, he lives in Tangerang which the environment used Sunda as their language in any transactional process, and he got the English language from the environments, which the parents provide him pictures and cassette that relate to the language, in this case, the writer tries to see focusing on processing English acquisition of Virendra which is happened in his environment and the sweet home.

\section{FINDING AND DISCUSSION}

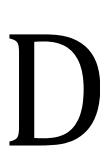
uring the observation, the researcher found that Virendra produced more Bahasa Indonesia than the native language and foreign language of his in the interaction process in his environment, and the language acquisition of Virendra during three weeks will be described as follow:

Week 1. In the first week of the research, the writer focuses on how Virendra acquired language in his school. Virendra produced more Bahasa Indonesia as the means of interaction in his school, because in the school the teacher mostly used Bahasa Indonesia in teaching, and in the interaction with friends Virendra produced Bahasa Indonesia more to make his easier in understanding the message of hers because many native languages happened in his kindergarten and the teacher suggested the learner to use Bahasa Indonesia in communication.

Week 2. This week, the writer saw Virendra activities in his environment, including his house and his interaction with his friends, in this time, Virendra seldom to come and play to his 
grandmothers' house, which surrounding by the scholars who use both Arabic and English as their means of interaction, in this chance Virendra imitate the speaking expressions that produced by the scholar.

Example:

The scholar says: Virendra, ta 'Ali (kesini)

Exactly Virendracome approach him who called him at that time,

Besides, when Virendra commanded 'Virendra, use the sandal' he exactly used it after the command.

Virendra understood what the interlocutor said but he often uses the language that the scholars use. When he met with his friends, he uses mostly Bahasa Indonesia and he used a little Sundanese as his native language, Virendra used Sunda in some question that referred to yes-no questions.

Example:

His aunty said: Virendrapeserkeunes? Virendra: Alim

Week 3. Virendra's parents invite the teacher to teach Virendra at home to teach science or language, and the interaction between them is running through the official language, it is Bahasa Indonesia. In social interaction, Virendra also used mostly Bahasa Indonesia among his friends because it easier for them to communicate.

Besides the result that the researcher finds based on the interaction process, the researcher sees that the parents of Virendra also motivate him to use Bahasa Indonesia and the foreign language both Arabic and English. It can be seen with the pictures hang in the wall of his rooms show the Arabic and English literature, it indicates that Parents and also environment affects Virendra development in using the language. In the last of the observation the researcher found that the percentage of Virendra's language is as follow:

Table 1. Percentage of Virendra's language

\begin{tabular}{lc}
\hline \multicolumn{1}{c}{ Language } & Percentage \\
\hline $\begin{array}{l}\text { Bahasa Indonesia (second } \\
\text { language) }\end{array}$ & $75 \%$ \\
$\begin{array}{l}\text { Sundanese (Native language) } \\
\text { Arabic and English (Foreign }\end{array}$ & $10 \%$ \\
Language) & $15 \%$ \\
\hline
\end{tabular}

After looking at all the activities of Virendra in producing the language among his environment, the writer finds that almost in his daily speaking expression he used 75\% (Bahasa Indonesia), 10\% (Sundanese) and 15\% (Both Arabic and English).it can be concluded that Virendra mostly used Bahasa Indonesia in the interaction process among his friends in the classroom and also in the house. Because the people around his used Bahasa Indonesia mostly in their daily speaking expression, and even though Sundanese is Virendra's native language, but he seldom to use it, it is only used in a certain occasion when he meets with the certain people who use Sundanese as a means of their communication. And Both Arabic and English are Virendra's foreign Languages, because he used it when he was in the grandmother's house which surrounded by the scholars who use Arabic and English as their tools in communication.

Therefore, Virendra can indicate both languages Arabic and English even though he can use it only in a little chance. And Virendra can identify the Arabic language easier than English because his parents introduced the 
Arabic earlier than English, his mother is a teacher who knows Arabic more and he teaches Arabic in one Islamic school in Tangerang. And for Virendra, some expressions used in Arabic is easier because it has similar pronunciation in Indonesia. And It can be seen as in table 2.

Table 2: Some similar words in Arabic and Indonesia

\begin{tabular}{ll}
\hline \multicolumn{1}{c}{ Arabic words } & Bahasa Indonesia \\
\hline Kursiyyun & Kursi \\
Kitabun & Kitab / Buku \\
Qirthosun & Kertas \\
Shobuunun & Sabun \\
babaya & Pepaya \\
\hline
\end{tabular}

Those words indicated that some Arabic expression is similar to Bahasa Indonesia and it makes Virendra able to use it. English is one of his foreign languages because the pictures that hang on the wall out only introduce it. But this little chance makes Virendra able to indicate some expression of English, for example, he knows about certain animals in English, Fruits and also things around his that showed in the pictures. As the writer mentions earlier, that the young learners learn based on what they hear and see, and they imitate easily when they find things that interested them, it also happened to Virendra, he seldom to use both English and Arabic when the people surrounding his use it in making interaction with others.

\section{CONCLUSION}

De to the theory above that acquiring language can happen in all aspects of the environments, and the case of Virendra indicate that language can be produced easily when the learner has the good support from the environment including parents and friends, and the writer found that Virendra produced Bahasa Indonesia more than another language, it can be motivated with the environment which used Bahasa Indonesia mostly in the communication, and it can be shown that almost in Virendra daily speaking expression he used $75 \%$ (Bahasa Indonesia), 10\% (Sundanese) and 15\% (Both Arabic and English).

As the writer has discussed previously, the younger is better and the older is faster in getting language acquisition, this condition appears the initial generalization of second language acquisition proposed by Krashen (1982, 1988). That they proceed through early stages of syntactic and more phonological development faster than children, and age-related constraint begins to set in as early as six for suprasegmental phonology, these constraints would make it increasingly difficult for the learner to acquire the second language without an accent, and it led to the existence of critical period that the learner should learn the second language after which of them had complete mastery of their first language. In conclusion, to enhance learners' language the parents should give more attention to the learners to use the appropriate language as their tools of communication.

\section{REFERENCES}

Baker, C. (2011). Foundations of Bilingual Education and Bilingualism. Canada: Multilingual Matters.

Freeman, D., \& Long, M. H. (1991). An Introduction to Second Language Acquisition Research. New York: Longman. 
Fromkin, V., Rodman, R., \& Hyams, N. M. (2003). An Introduction to Language. USA: Thomson/Heinle.

Goodz, N. S. (1989). Parental Language Mixing in Bilingual Families. Infant Mental Health Journal, 10(1), 25-44. https://doi.org/10.1002/1097-0355

Krashen, S. D. (1982). Principles and Practice in Second Language Acquisition. New York: Pergamon Press.

Krashen, S. D. (1988). Second Language Acquisition and Second Language Learning. Prentice-Hall International.

Rossetti, L. M. (2009). Communication
Intervention: Birth to Three. Canada: Thompson Learning.

Sande, L. (1998). The Relationship between Language and Intelligence. Retrieved from https://eric.ed.gov/?id=ED470647

Yusuf, Y. Q. (2009). A Case Study on Infant Bilingual Acquisition. Modern Journal of Applied Linguistics, 1(5), 303-330. Retrieved from http://www.mjal.org/

Yuvaraj, A. (2009). Age Factor and Its Implications for Teaching English to Young Learners. Modern Journal of Applied Linguistics (MJAL), 1(6), 0974-8741. 